\title{
Corporations Républicaines: The Revolutionary Idiom of Parisian Workers in 1848
}

\author{
WILLIAM H. SEWELL, JR.
}

Institute for Advanced Study

When the insurrection of February 1848 chased Louis-Philippe from the throne and brought a provisional republican government to power, the Parisian workers who had made the insurrection suddenly found themselves at the center of the political stage. As the heroes and victors of the revolution, they immediately won important concessions: the declaration of the right to work (the 'droit au travail'), the opening of the National Workshops, and the establishment of the Luxembourg Commission-a body composed of representatives of all the capital's trades, chaired by the socialist theorist Louis Blanc, which was to discuss the organization of labor and make proposals to the government. The workers responded to this revolutionary situation with a monumental outpouring of words and action, attempting to construct a new social and political order based on labor and its rights. In this paper I shall try to describe and interpret one prominent feature of the workers' projects for revolutionary transformation: their use of language and of organizational forms that were apparently borrowed from the corporate system of the old regime.

The interpretive framework of most labor historians has led them to overlook all continuities and affinities between the corporate system of the old regime and the workers' movement of the nineteenth century. According to this dominant framework, the corporate regime, which was already moribund by 1789 , was utterly swept away in the French Revolution, while nineteenth-century labor organizations were created in response to the pressures of the new industrial economy-an economy for which the

An earlier version of this paper was presented at the annual meeting of the Society for French Historical Studies in Berkeley, California, in April 1977. I am currently preparing a larger study on the conceptual and institutional framework of labor in France from the old regime to 1848 . This paper is a preliminary report on that study.

$0010-4175 / 79 / 2354-2375 \$ 2.00$ (C) 1979 Society for Comparative Study of Society and History 


\section{I96 WiLLiAM H. SEWELL JR.}

French Revolution had created the preconditions. ${ }^{1}$ Given this framework, the persistence of words, phrases, ideas and organizational forms that hearken back to the old regime must be seen as deeply paradoxical. Yet even the most cursory reading of materials written by and for revolutionary workers in Paris in the spring of 1848 reveals that the words corporation, corps d'état, état, corps de métier and so on were used over and over again in their discourse -in speeches, petitions, statutes of organizations, newspaper articles, and manifestoes. ${ }^{2}$ Workers used these words to refer both to the trades they practiced and to the organizations which they were busily constituting in these trades in the immediate aftermath of the revolution. In fact, the trade corporations they were constituting were intended as democratic organizations of all workers in the trade, so the two things, the trade and its organization, were in principle one and the same. These corporations - to use the word employed most commonly in 1848-occupied a central place in the workers' revolutionary projects. They were central, first, in the sense that constituting and animating such democratic corporations absorbed an enormous amount of the revolutionary workers' time and energy. ${ }^{3}$ But they were also central in a deeper sense. For these corporations came to be envisioned by workers as essential elements, as constituent units, of the new socialist political order they were attempting to create. Indeed, I would argue that we cannot hope to understand what the workers meant by their cherished vision of a 'République démocratique et sociale', without examining in some detail the 'corporations ouvrieres' (workers' corporations) which they constituted in the spring of 1848 .

What was the nature of these corporations that were constructed in the spring of 1848 in nearly all of the capital's trades? The Provisional Government's repeal of restrictions on the liberty of association made it possible for workers to openly construct labor organizations for the first time, and

1 This view informs nearly all of the older synthetic histories of the French labor movement, e.g. Edouard Dolléan, Histoire du mouvement ouvrier, 3 vols. (Paris, 1936-53); Dolléans and Gérard Dehove, Histoire du travail en France: mouvement ouvrier et legislation sociale, 2 vols. (Paris, 1953-55); George Lefranc, Histoire du mouvement ouvrier en France des origines a nos jours (Paris, 1947); Paul Louis, Histoire du mouvement syndical en France, 2 vols. (Paris, 1947). The best recent synthetic essay on the French labor movement is Bernard H. Moss. The Origins of the French Labor Movement; The Socialism of Skilled Workers, 1830-1914 (Berkeley, 1976). While his interpretations challenge earlier accounts on many grounds, Moss agrees with them in seeing no significant continuity with the corporate system of the old regime.

2 The best source for the revolutionary workers' discourse is Remi Gossez, Les Ouvriers de Paris, book one, L'Organisation, 1848-1851, vol. 24 of the Bibliothèque de la Révolution de 1848 (La-Roch-sur-Yon, 1967). Les Murailles révolutionnaires de 1848. prefaced by Alfred Delvau (Paris, 1868), 2 vols, also has a great deal of valuable material. However, such recent collections of documents as Maurice Agulhon, Les Quarante-Huitards (Paris, 1975) and Roger Price, 1848 in France (Ithaca, N.Y., 1975) contain very few documents relevant to the arguments presented in this paper.

${ }^{3}$ The best description of the workers' efforts to consititute new corporations is Gossez, Les Ouvriers de Paris. 
the need to elect representatives of each trade to the Luxembourg Commission provided an additional stimulus. Often these newly constituted corporations were expanded or elaborated versions of preexisting mutual aid societies or illicit workers' associations, but in some cases corporations were formed in trades that had hitherto been completely unorganized. The goals of these corporations were well summarized in the statutes of the Société des Ferblantiers, founded in April of 1848: 'maintaining wages and propagating the good spirit of cordiality that ought to exist between men of the same profession.' 4

The preferred means of 'maintaining wages' was a public agreement with masters on a tarif, that is, a schedule of wages. The idea of a binding and uniform schedule of wages was of course a very old one; setting and enforcing such schedules was a routine task of corporations of the old regime. Under the legislation of the Revolution, tarifs could no longer have any legal validity, but there continued to be tacitly accepted tarifs in many artisan trades in the $1820 \mathrm{~s}, 30 \mathrm{~s}$ and $40 \mathrm{~s}$, and these were often reached by some form of collective bargaining between workers and masters. ${ }^{5}$ One of the primary tasks that workers' corporations set for themselves in 1848 was to make such tarifs public, official, and binding. In March and April of 1848 , when the prestige of the Luxembourg Commission was at its height and the workers appeared to have won the revolution, many workers' corporations won very favorable tarifs from the masters. Typically these were negotiated by commissions paritaires, as they were called, commissions composed of an equal number of masters and workers, often including the corporation's delegates to the Luxembourg Commission. In many cases the conventions containing such tarifs were then signed publicly before the Luxembourg Commission, giving them the symbolic backing of public authority. ${ }^{\circ}$ These conventions, of course, were generally of very short duration. Once the Provisional Government had relinquished power to a conservative National Assembly and the Luxembourg Commission had itself been dissolved, many masters ceased to apply the agreed-upon tarif, and the workers were thrown back on their usual resource in such matters: informal collective bargaining backed up by the threat of work stoppages. But despite the setback, officially sanctioned, public, and binding tarifs remained an essential goal of revolutionary workers and their corporations throughout the Second Republic.

4 Ibid., p. 156.

5 That tacit tarifs were very common can be documented by examining George and Hubert Bourgin, eds. Le Régime de l'industrie en France de 1814 à 1830: Les patrons, les ouvriers et l'état. Recueil de textes. 3 vols. (Paris, 1912-41); J. P. Aguet, Les Grèves sous la monarchie de juillet (1830-1847): Contribution à l'étude du mouvement ouvrier français (Geneva, 1954); and Associations professionnelles ouvriers, 4 vols. (Paris, 1894-1904), published by the French governments' Office du travail.

- See Gossez, Les Ouvriers de Paris, pp. 67-87, 268-74. 


\section{I98 WILLIAM H. SEWELL JR.}

The goal of 'propagating the good spirit of cordiality that ought to exist between men of the same trade' was best embodied in a whole series of practices of mutual assistance. Parisian corporations of 1848 collected dues so that they could distribute aid to members or to their survivors in times of need. The corporation would provide medical care and a small payment to sick members, pensions to retired members and to widows or orphans, and sometimes payments to members who were out of work. Furthermore, when members died they were to be given a funeral by the corporation. These practices were of course of immediate economic benefit to members. But they also indicated that the corporation was thought of as a genuine moral community, that its concerns spread beyond the working life of members to embrace the well-being of the whole person of every worker in the trade. The corporate funeral was a particularly potent statement of this solidarity, demonstrating that members of corporations were bound to one another both in life and in death. As the Fraternal and Industrial Society of Locksmiths and Mechanics said in its statutes, the corporation was to "come to the aid of all its members by all means in our power from their admission up to and including their burial., ${ }^{7}$ This notion of the trade as a solidary moral community, like the notion of a uniform and binding tarif, can be traced right through the early nineteenth century and back to the trade corporations of the old regime. ${ }^{8}$ Under the old regime every trade corporation had its adjunct religious confraternity, which usually had precisely the same practices of mutual aid as workers' corporations in 1848: benefits for the needy, the sick, and widows and orphans, and corporate funerals. And precisely the same practices were the official raison d'être of the hundreds of legally registered mutual benefit societies that were founded by workers during the Restoration and the July Monarchy. In this respect, the workers' corporations of 1848 were simply reproducing a long corporate tradition.

But workers' corporations in 1848 also had some more novel features. First, they very frequently included provisions for setting up associations of production - what we would call producers' cooperatives. In some cases these were first established as a refuge for workers who were on strike or unemployed. But they were also intended as the first step toward supplanting all private production with associative production, either with the aid of

7 Quoted in ibid., p. 213.

${ }^{8}$ Perhaps the best-documented example of such continuity is Jean Vial, La Coutume chapelière: histoire du mouvement ouvrier dans la chapellerie (Paris, 1914). See also Paul Chauvet, Les Ouvriers du livre en France, 2 vols. (Paris, 1959); Robert J. Bezucha, The Lyon Uprising of 1834: Social and Political conflict in the Early July Monarchy (Cambridge, Mass., 1974), esp. pp. 1-47; and Joan W. Scott, The Glassworkers of Carmaux (Cambridge, Mass., 1974), esp. pp. 19-52. For Marseille, see Sewell, 'Social Change and the Rise of Working-Class Politics in Nineteenth-Century Marseille,' Past and Present 65 (1974), esp. 81-82, 91-92, 104-05. 
the state or by driving private producers out of business through competition. The goals of workers' corporations, therefore, went beyond the short-range ameliorative one of establishing favorable tarifs to the longrange revolutionary one of abolishing private property altogether. ${ }^{9}$ Second, where the trade corporations of the old regime were involved in unceasing mutual suspicion and hostility, and where the mutual aid societies of the $1820 \mathrm{~s}, 30 \mathrm{~s}$ and 40 s generally stuck to the concerns of their own particular trade, workers' corporations of 1848 were explicitly dedicated to the solidarity of all laborers and all trades. The preamble to the statutes of the Société Typographique was typical when it proclaimed as a founding principle 'the most complete solidarity possible between all workers' corporations.' 10

Finally, workers' corporations of 1848 were republican in structure. Trade corporations of the old regime had been totally dominated by the masters, with journeymen and apprentices considered to be under the masters' paternal authority. Mutual aid societies of the $1820 \mathrm{~s}, 30 \mathrm{~s}$ and $40 \mathrm{~s}$ usually did not include masters; however, they normally encompassed only a small elite of the workers in the trade. But workers' corporations of 1848 were radically democratic in form. All workers exercising the trade were members, and all delegates or officers of the corporation were chosen by universal suffrage. ${ }^{11}$ The workers' corporation, in short, was a microcosmic version of the democratic and social republic. Based on freedom of association, proclaiming the solidarity of all laborers, and governed by universal suffrage, workers' corporations were little republics that would organize labor in productive harmony in every trade and maintain brotherly solidarity by mutual aid and protection. It was thus hardly surprising that workers came to see their corporations as the proper constituent units of the new revolutionary state.

What was the place of these little republics in the workers' overall project of constructing a 'République démocratique et sociale?' In the first place, it was clear that corporations were themselves to be public actors. Labor, all observers agreed, was the central issue of the French revolution of 1848 . And since, in the eyes of the workers, the domain of labor was naturally divided into corporate trade communities, it followed that representation of labor in the public sphere should take a corporate form. This tendency to organize political life in the framework of trade corporations was manifested in a number of ways in the spring of 1848 . Corporations participated as units, each marching behind its own banner, in the endless series of political processions and demonstrations that shook the capital in the spring of 1848 - from the demonstrations around the Hotel de Ville on 25

9 Bernard H. Moss, French Labor Movement, pp. 41-8.

10 Gossez, Les Ouvriers de Paris, pp. 198-99.

11 Ibid., pp. $239-42$. 
and 28 February, to the famous journées of 17 March, 16 April, and 15 May. ${ }^{12}$ In 1848 the workers took symbolic possession of the streets of Paris, announcing themselves as the sovereign people by seizing the Revolution's traditional public space. And in these periodic revolutionary spectacles, the sovereign people presented itself not as an undifferentiated sans culotterie as it had in the year II, but as an aggregation of corporations ouvrières.

The same tendency was manifested in the electoral campaign of April 1848. As elections for the Constituent Assembly neared, each corporation constituted itself as an electoral committee, and like the many political clubs that had sprung up since February, they listened to a string of candidates who went about from club to club and corporation to corporation to solicit votes. But the corporations in fact nearly always chose to endorse a candidate from their own trade. Indeed, this tendency soon became alarming to Louis Blanc and the delegates to the Luxembourg Commission, who attempted to bring order to this quest for worker representation by drawing up a single unified list of candidates to be supported by all the corporations represented at Luxembourg. But this effort was too little and too late: the Commission's list was not published until the day before the election, and by then many other workers had long since launched their candidacies. As a result, the campaign to elect workers to the Assembly was a failure; and only one of the Luxembourg's worker candidates was elected. But it is instructive that this failure arose largely out of the desire of each corporation to have a deputy of its own in the Assembly, and to act as an autonomous political unit during the campaign. ${ }^{13}$

The idea that corporations should become constituent units of the state was in fact much encouraged by Louis Blanc and the Luxembourg commission. Officially, Luxembourg was an advisory commission, without any legislative power. All it could do was make recommendations to the National Assembly. But in the discourse of revolutionary workers, Luxembourg was assigned a much more lofty place: to them it was nothing less than the grand republican spectacle of the people governing itself. As the radical journal Le Semeur put it shortly after the opening session of the Commission: 'The Revolution is social, it is there in its entirety in that session held on March first at Luxembourg, where 150 to 200 workers met in order to resolve with the government the great problem of their destiny. ${ }^{14}$ Nor was Louis Blanc ready to discourage such grandiose interpretations. As he said in a speech to the Commission on March 28,

12 On the journées, see George Duveau, 1848 (Paris, 1965), and Gossez, Les Ouvriers de Paris, pp. 19-20, 37-39, 174, 244-47, 265.

${ }^{13}$ Gossez, Les Ouvriers de Paris, pp. 249-57.

14 Ibid., p. 23. 
It is an admirable thing that we have succeeded in establishing the Etats Généraux du Peuple. You are here an assembly of deputies, an assembly of Deputies of the People. Whether the Nations Assembly is installed or not, I have confidence that this one shall not perish! ${ }^{15}$

Luxembourg, in short, was seen as a kind of parallel National Assembly, whose task was to legislate the organization of labor, or, as the delegates of the cabinet makers put it, to elaborate la consitution du travail' (the constitution of labor). ${ }^{16}$ What was represented in this parallel National Assembly was the labor of the French nation, and the national labor was represented, of course, by delegates of corporations. Corporations thus formed the electoral constituencies-and the constitutent units - of a kind of embryonic parallel government. Moreover, there is no doubt that the 'constitution of labor' which the Luxembourg Commission was engaged in elaborating would in turn be based on democratically constructed and state-aided corporations. The implicit revolutionary project of the Luxembourg was thus nothing less than a radical reordering of the state and the society, with democratic corporations at the base and an assembly of national labor at the top; a transformation of the traditional republican doctrine of popular sovereignty into a socialist vision of labor sovereignty. This was the characteristic socialist vision of Parisian workers in the Revolution of 1848 .

This, of course, never came to pass. With the election of a conservative National Assembly, the promises made by the provisional government were one by one withdrawn. The Luxembourg Commission was dissolved in the wake of the disastrous attempted insurrection of May 15, and finally the National Workshops were dismantled in June, resulting in the bloody workers' uprising of the 'June Days.' But ephemeral as the projects of Luxembourg proved in practice, their impact on the subsequent history of French workers' movements was deep and lasting. Before the spring of 1848 , socialism was a series of more or less abstract and esoteric doctrines, generally of uncertain relevance to political life, preached by eccentric prophets who were more or less out of touch with the mass of workers: Proudhon, Pierre Leroux, Philippe Buchez, Etienne Cabet, Louis Blanc and the like. But in March and April of 1848, the essential features of their doctrines - their critique of competition, their assertion of the centrality of labor in social life, their proclamation of the need for associative production-were suddenly embraced by the vast mass of Parisian workers, who embodied them in their metamorphosed corporate trade communities, and projected these associative corporations of labor as the basis of a new social and political order. During that tragic but fertile spring, socialism was permanently wed to republicanism, and the resulting socialist republicanism was given a corporate form. This corporate vision of socialism, which Bernard Moss has characterized as 'federalist trade socialism,'

15 Ibid., p. 225. 16 Les Murailles révolutionnaire, i, 286. 
characterized the French labor movement right down to the First World War and the Bolshevik Revolution, as Moss has convincingly demonstrated in his recent book. ${ }^{17}$ For all the utopianism so roundly denounced by Marx in his Class Struggles in France, the ideological projects of Luxembourg and the Parisian workers in 1848 had a deep and formative practical effect on the organization and political development of French workers over the next half-century.

If this interpretation of working-class ideology in 1848 is right, it implies a major revision of at least one prevailing assumption of French labor history: that of radical discontinuity between the corporate system of the old regime and the workers' movement of the nineteenth century. We can no longer think of socialism and the workers' movement as having been generated, unmediated, out of the exploitative dynamics of the new capitalist system. Rather, we must recognize that the workers who created or elaborated early French socialism already possessed a rich corporative cultural heritage and that their responses to capitalist exploitation were medicated by corporative ideas, values, terms and customs. The result was a movement and a social vision that opposed capitalism in the name of labor and democracy, but that did so in deeply corporate terms. There was, in short, a real and definable continuity between the corporate system of the old regime and the socialism of 1848 .

We must be careful, however, not to misconstrue the nature of this continuity. For it would be all too easy to conclude that the socialist vision of 1848 was essentially backward-looking, a nostalgic and misguided attempt to restore the corporate system of the old regime. But such a conclusion would be fundamentally wrong. The workers who elaborated corporate projects in 1848 were self-conscious progressives and good revolutionaries. They abhorred the old regime and had no desire to restore any past, let alone that one. They may have been conscious that bodies called corporations or corps d'etat or corps de métier had existed under the old regime, but when they used the terms they were not referring to these archaic and, from their point of view, utterly discredited insititutions. Rather, their use of corporate terminology and organizational forms came directly out of the standard practices of skilled workers in the 1830s and 1840 s, who routinely referred to their trades and their trade organizations as corps d'état, corps de métier and corporations. Moreover, the labor organizations they constructed were invariably corporate in form and in tone, with practices of mutual aid and corporate funerals, and pervaded by an assumption that the trade was a moral community. It was these nineteenth-century workers' corporations, not the masters' corporations of the old regime, that provided the revolutionary workers of 1848 with their 
model. They were looking not backward, but outward at the day-to-day struggles and practices of skilled workers of their own time.

Of course the nineteenth-century workers' corporations themselves were in some sense modeled on the trade corporations of the old regime. But continuity between the old regime and the nineteenth-century corporations was complex and transformative, not simple and genetic. Corporations of the old regime were officially recognized, privileged legal institutions dominated by the masters of each trade. These institutions were irrevocably abolished in the French Revolution. But neither the assumption that the trade was a moral community nor the language, rituals and organizational practices that embodied and expressed this assumption could be abolished quite so simply by legislative fiat. On the contrary, they were taken up by workers and gradually transformed into a working-class idiom of opposition to the masters and to the dominant bourgeois ideology of laissez-faire. By 1848 , corporate language and assumptions had come full circle. Rather than a mark of counterrevolutionary sentiment, they became a revolutionary idiom opposed to the complacent liberalism of the bourgeoisie. In this way, the sense of solidarity and of hostility to competitive individualism that were hallmarks of French socialism were a transformed version of the corporate ideal of the moral community of the trade. The Parisian revolution of 1848 deserves to be recognized as the culminating episode in this historic transformation. 